\title{
LPCAT1 Gene
}

National Cancer Institute

\section{Source}

National Cancer Institute. LPCAT1 Gene. NCI Thesaurus. Code C152058.

This gene is involved in the conversion of lysophosphatidylcholine to phosphatidylcholine. 